Western University

Scholarship@Western

Aboriginal Policy Research Consortium International (APRCi)

$11-2011$

\title{
Conflict in the Statutory Elicitation of Aboriginal Culture in Australia
}

James F. Weiner

Follow this and additional works at: https://ir.lib.uwo.ca/aprci

Part of the Indian and Aboriginal Law Commons, and the Social and Cultural Anthropology Commons

Citation of this paper:

Weiner, James F., "Conflict in the Statutory Elicitation of Aboriginal Culture in Australia" (2011). Aboriginal Policy Research Consortium International (APRCi). 406.

https://ir.lib.uwo.ca/aprci/406 
This article was downloaded by: [University of Western Ontario]

On: 30 October 2012, At: 09:23

Publisher: Routledge

Informa Ltd Registered in England and Wales Registered Number: 1072954 Registered

office: Mortimer House, 37-41 Mortimer Street, London W1T 3J H, UK

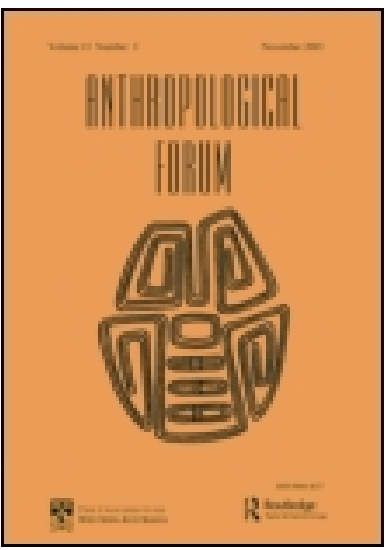

\section{Anthropological Forum: A J ournal of Social Anthropology and Comparative Sociology}

Publication details, including instructions for authors and subscription information: http:// www.tandfonline.com/loi/ canf20

\section{Conflict in the Statutory Elicitation of Aboriginal Culture in Australia \\ J ames F. Weiner \\ Version of record first published: 19 Oct 2011.}

To cite this article: J ames F. Weiner (2011): Conflict in the Statutory Elicitation of Aboriginal Culture in Australia, Anthropological Forum: A J ournal of Social Anthropology and Comparative Sociology, 21:3, 257-267

To link to this article: http:// dx.doi.org/ 10.1080/ 00664677.2011.617676

\section{PLEASE SCROLL DOWN FOR ARTICLE}

Full terms and conditions of use: http://www.tandfonline.com/page/terms-andconditions

This article may be used for research, teaching, and private study purposes. Any substantial or systematic reproduction, redistribution, reselling, loan, sub-licensing, systematic supply, or distribution in any form to anyone is expressly forbidden.

The publisher does not give any warranty express or implied or make any representation that the contents will be complete or accurate or up to date. The accuracy of any instructions, formulae, and drug doses should be independently verified with primary sources. The publisher shall not be liable for any loss, actions, claims, proceedings, demand, or costs or damages whatsoever or howsoever caused arising directly or indirectly in connection with or arising out of the use of this material. 


\title{
Conflict in the Statutory Elicitation of Aboriginal Culture in Australia
}

\author{
James F. Weiner
}

In order for Aboriginal rights and interests to be recognised under the Native Title Act (1993), such rights and interests must arise from laws and customs that can be shown to have continuity with the particular set of laws and customs that existed at the time of sovereignty, or, at least, at the time of first European contact. This interpretation of continuity has been applied in Australian native title cases since the High Court's Yorta Yorta decision (Yorta Yorta $\mathrm{v}$ the State of Victoria [2002] HCA 58). Yet today's Aboriginal native title claim groups are also required to participate in other statutory ventures outside of the native title domain. For example, 'tribal' representatives in north Queensland are obliged to represent their interests on the Wet Tropics Management Authority, and the Great Barrier Reef Marine Park Authority. In native title terms, however, the activity and time spent participating in these ventures do not 'count' as instantiations of traditionally based rights and interests. Furthermore, the powers and rights granted to Aboriginal groups under these statutory ventures are often in conflict with the strictures of current native title interpretations of 'traditional law and custom and rights and interests'. The effect is to elicit versions of Aboriginal action that may contradict each other legally. In this paper, I discuss some examples of these institutional conflicts engendered by the statutory actions of state and federal government, and comment on the implications for the contemporary Aboriginal articulations of identity and tradition.

Keywords: Aboriginal; Native Title; Institutional Conflict

\section{Introduction}

Native title was introduced in Australia in 1992 with the High Court case of Mabo (Mabo v Queensland No 2. [1992] HCA 23; 'Mabo'). In this case, the High Court recognised that Meriam people in the Torres Strait had been in possession of the island of Mer before the acquisition of sovereignty over Australia by the British

Correspondence to: James F. Weiner. Visiting Fellow, Resource Management in Asia-Pacific, Research School of Pacific and Asian Studies, The Australian National University, P.O. Box 82, Curtin, ACT, 2605, Australia.

Email: jamesfweiner@gmail.com

ISSN 0066-4677 print/1469-2902 online

(C) 2011 Discipline of Anthropology and Sociology, The University of Western Australia http://dx.doi.org/10.1080/00664677.2011.617676 
Crown in 1788. Furthermore, although the system by which the Meriam people possessed and occupied their land was not a European system of property rights as such, the High Court concluded that the common law recognised these rights, and the Indigenous system of law and custom that underwrote them. The Mabo decision put an end to the fiction of terra nullius as it was known in Australia: that the British settlers arrived in a land 'empty' of people and hence 'empty' of law and property in the European sense.

The High Court thus concluded that a concept of native title was recognised at common law and, the next year, the Labor-led Parliament passed the Native Title Act (1993). As part of the Act, Native Title Representative Bodies (NTRBs) were set up and funded by the Federal government to initiate applications by Indigenous communities to the Federal Court for recognition of native title rights and interests.

Over 1900 separate native title applications have since been lodged, however, of those that have been determined through a Full Federal Court process (165), in only 62 cases has native title been found to exist in the entire claim area. Of the remaining applications, many have been removed after Court administrative decisions, both positive and negative, for example, where overlapping claims have been either merged by agreement between the parties, or one or more parties have been 'struck out' after their claim has been found to be without sufficient evidence to proceed. More than 450 applications remain to be resolved. ${ }^{1}$

Part of the explanation for the poor results in positive determinations of native title applications since 1994 was that while native title was recognised at common law, it was recognised only to the extent that it was said to co-exist with that common law and the other laws of the Crown. In a number of key native title cases-for example, the High Court's Wik (Wik peoples $v$ the State of Queensland [1996] HCA 40) decision that led to a comprehensive revision of native title by the Howard government in 1998 (the so-called Wik amendments), and the High Court's Miriwung-Gajerrong decision (Ward $v$ the State of Western Australia [2002] HCA 28)-the nature of this co-existence has been progressively clarified, usually by acknowledging that other rights (such as those of pastoralists or the government) are recognised separately from native title rights, which were previously more narrowly defined. Other decisions have increasingly given more expansive powers to the government to extinguish native title over certain tenures.

In many important respects, the fact of 'co-existence' established the legal framework for a wide range of 'official' relationships between Aboriginal traditional law and custom, and the law of the Australian state. Indigenous and settler Australians have been co-existing practically (in the widest sense, socially, geographically and historically), since the first arrival of Europeans. However, it is only in recent times, with the passage of various state and federal statutes that define and manage Australian Aboriginal cultural heritage, as well as Aboriginal land rights legislation - the most significant of these being the Aboriginal Land Rights (Northern Territory) Act (1976), through to the Native Title Act (1993) - that 
the law has been confronted with the task of assessing and delimiting the nature of Indigenous culture, and the rights and interests that can still be traced to it in the present.

Australian Aboriginal culture, both as a mode of occupation of space and time and as a 'culture' seen by us analogously as a set of rules and laws, is therefore not autonomous. By the very fact of its recognition by the laws of the Australian state and society, it is incorporated into that system of law. With recognition comes some power and leverage within that society, but it comes at the expense of any sense of a radical separation from, or autonomy within, the country of Australia. Many laws of Australia pertain to land and its resources. All of these laws must now calibrate themselves with regard to the existence of native title, and the inconsistencies between the Native Title Act and pre-existing legislation have had to be continuously clarified. In this article, I wish to address one such dimension of this inconsistency in the contemporary period, in addition to contemplating the anthropological idea that the inconsistency itself is what is conventional now in Australia.

\section{Native Title as a 'Social Fact'}

I want to start by relaying a comment that anthropologist and native title consultant, John Burton (pers. comm.), made to me, and this is a comment that every native title anthropologist could make for themselves: 'I went to make an appointment with elder X to talk about his native title and he told me he couldn't meet with me, he was on a committee that was talking to the State about Indigenous management of rainforests and had to attend a meeting'. In other words, his informant was saying to him: 'I have no time to pursue my native title, as I am busy exercising the rights over land that the State has already granted me outside of the whole process'. It is these rights outside of native title that I want to identify first.

Because as anthropologists we would wish to think of native title as encompassing the entirety of traditional connection to land possessed by various Aboriginal landholding groups, we tend to look at all other rights to land that Aboriginal people claim or strive to obtain as a variety of native title right in some important sense. Some time ago, in my review (Weiner 2003) of David Martin and Christos Mantziaris' (2000) book Native Title Corporations, I spoke of native title as a 'total social fact' or a 'total institution'. I did not, and still do not, think that there is anything anthropologically contentious about such a characterisation. If we are charged with describing the relationship to a territory or a territorial life space of any Aboriginal land-holding group, then by the terms of Aboriginal culture with which we are familiar, this encompasses every aspect of their religious, economic and political life. Our ethnographic understanding is that each Aboriginal group was itself laid down within a specific place and with a specific language in a landscape during the creative time, which henceforth becomes the mythological 'charter' for the distinctive features of the group itself. For Australian Aboriginal people, the land orients everything in human life and the religious institutions that manage human 
authority over and knowledge of land become central to the social, economic and reproductive life of each group.

But as Martin and Mantziaris (2000) and many others have pointed out, such regimes are now subsumed within an encompassing Euro-Australian nation state, whose laws regulate the manner in which this total Indigenous landscape, in all its distinct local manifestations, is recognised in the most comprehensive sense of the term. As David Martin (pers. comm.) said to me, if, for Aboriginal Australians, the Creator Beings made the world within which humans live, it is the courts of Australia which now have the power to recognise and authenticate the power of these Creator Beings, once again substituting a man-made world for the one bequeathed to Aboriginal Australians, but not conceived as being 'made' by themselves at all.

From the point of view of this encompassing system, there are two features of its legal underpinning that I wish to draw attention to here. First, it is not 'global' in the sense that Lévi-Strauss (1969) called societies that possessed elementary kinship structures global in that it does not articulate itself as a totality; the laws that govern it do not emerge from a single act of creation (what single act created the 'common law'?), but have emerged through time in a piecemeal 'organic' fashion.

Second, and following on from this observation, the law has the quality of parsing the world, and human action within it, into discrete spheres. We not only have distinct levels of jurisdiction among local government, state and federal laws and courts, but we also have functionally-defined departmental structure to public, civic and official life, which identify our distinct institutions: medical, labour, educational, financial etc., and their attendant body of laws. This parsing is particularly visible in the way property rights in land are defined, for, as I intimated earlier, property law in Australia sees no piece of land as having a single encompassing right of ownership over it-land is always held by more than one set of persons each of whom have different kinds of rights in it (see Glaskin 2003, Sutton 2003, Rigsby 1998). ${ }^{2}$

\section{Partial Rights}

Let me tack now momentarily, to these various laws and bodies of law provide the legal recognition of different institutions, functions, expertises and so forth that contribute to Australian society and its common weal. As Martin and Mantziaris (2000) point out, the recognition of any of these discrete spheres are only ever partial in their contribution to the whole that is the Australian Commonwealth, despite the claims they make to internal coherence within these separate disciplines. Although I invoke Marilyn Strathern's (1999) notion of 'partiality' here, this effect was noticed many years previously by American anthropologist Robert Redfield (1960) when he referred to Mexican peasant communities as being 'part cultures' as a result of their necessary dependence upon external markets within a national economy.

Politically and culturally, we are in a period of history where, among other things, multi-culturalism is the avowed policy of social inclusion. The notion of the 'stakeholder' is also part of this policy of social inclusion, yet the concept of the 
'stakeholder' is but an updated version of the partible, multiple nature of rights in land and the relation among rights-holders that has always founded common law understandings of ownership of land. This broad movement towards social inclusion encompasses the recognition of Indigenous rights to land based on their original occupation of the continent. 'Projects' might have a wholeness and vision, but the human personnel and interests that converge on and are elicited by them are contingent and situational and have competing and inconsistent relations to land and property.

I now turn to the case I wish to employ as an example in this analysis, that of the Mamu native title claim to country around Innisfail, northern Queensland. Because of the established link in public discourse between any land-related enterprise and indigeneity, the state of Queensland has sought to include Indigenous people in various enterprises. In north Queensland, the Wet Tropics Management Authority (WETMA) has a board of Indigenous representatives, each one representing one of the bama wabu or 'rain forest people' of that area. In one sense, this is a form of Indigenous regionalism that rests on prior, pre-settlement relationships and perceptions of inter-culturality (see Merlan 1998), and also reconfigures such relationships in the interests of contemporary state goals. Similarly, the Great Barrier Reef Marine Park Authority (GBRMPA) has invited each native title claim group from the coastal areas associated with the Great Barrier Reef to participate in what they term a 'Traditional Use of Marine Resources Agreement' (TUMRA). This too is a 'region' albeit one that has does not 'reach back' to any associations pre-sovereignty. ${ }^{3}$

In both cases, representatives of current native title claim groups have been granted rights and authority over lands and waters that they so far have been unsuccessful in obtaining as native title claimants. For example, the State of Queensland has aggressively fought against the extension of native title to offshore areas; the Torres Strait Islanders have only recently secured native title rights to sea areas (Torres Strait Islanders v State of Queensland No. 2 [2010] FCA 643). For this reason, many coastal groups, such as the Mamu of the Innisfail area, have excluded all offshore areas from their claims. In Mamu, those of us assisting the claimants with their native title claim have included in the claim area only those islands that the claimants can decisively prove to have inhabited and used at the time of first contact (see Figure 1).

However, the TUMRA offered by the GBRMPA has granted these coastal groups Indigenous authority over a segment of the Great Barrier Reef-even though they never were able to go that far out to sea in pre-contact times [see Figure 2] - and the right to take a certain number of marine resources, such as sea turtles and dugongs, each year. Although such rights are not supported by the content on the current Mamu native title application, the terms of the GBRMPA are that no agreement made with Indigenous custodians shall be deemed to be affected by any decisions made under the Native Title Act.

Section 211 of the Native Title Act allows Aboriginal people to continue engaging in resource-taking activities for their own personal use, even when such of their native title rights have been curtailed by laws pertaining to taking of resources, such as fishing 


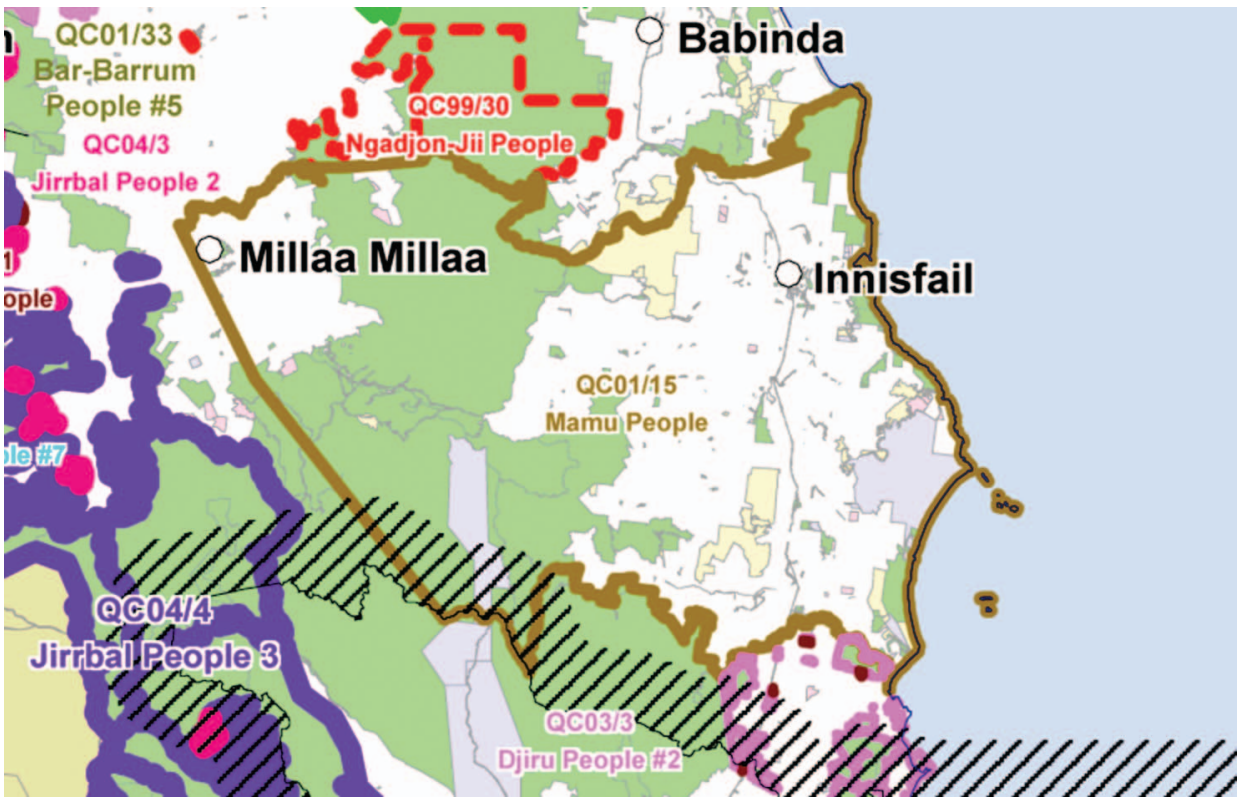

Figure 1. Mamu Native Title Claim Area

Source: http://www.nntt.gov.au/Publications-And-Research/Maps-and-Spatial-Reports/ Pages/National-Maps.aspx (accessed 8/9/11).
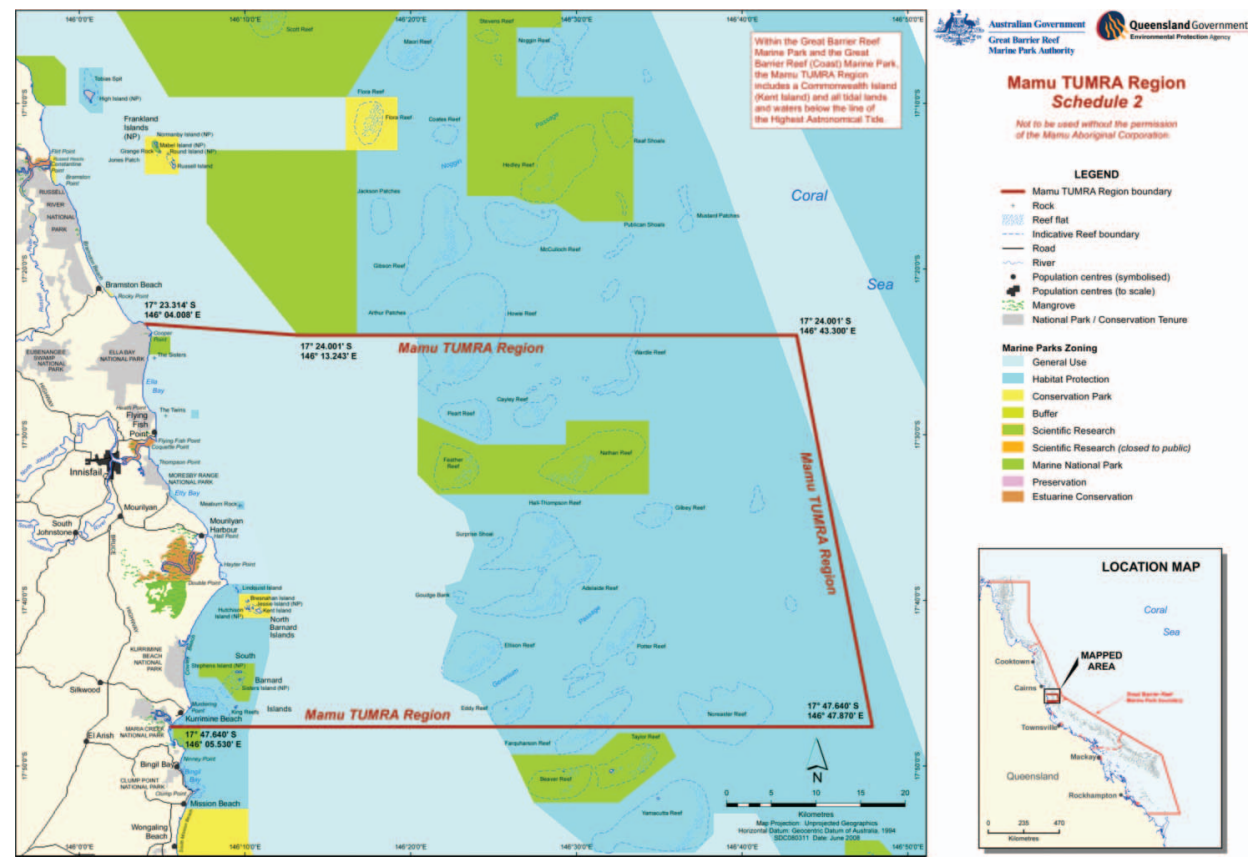

Figure 2. Mamu TUMRA Region

Source: http://www.gbrmpa.gov.au/our-partners/traditional-owners/traditional-use-ofthe-marine-park (accessed 8/9/11). 
and game limits and prohibitions, or other permits or licensing. Following the High Court decision in the Yanner case (Yanner v Eaton [1999] HCA 53; 'Yanner'), there have been other more local implementations in line with it, for example:

[I]f the exercise or enjoyment of native title rights and interests in relation to land or waters consists of or includes carrying on hunting, fishing and gathering, and some other law prohibits or restricts persons from carrying on that class of activity other than in accordance with a licence, permit or other instrument granted or issued under the law ... in those circumstances the law does not prohibit or restrict native title holders from carrying on the class of activity where they do so ... for the purpose of satisfying their personal, domestic or non-commercial communal needs; and in exercise or enjoyment of their native title rights and interests. (Lewis $v$ Wanganeen and Harradine [2005] SASC 36, paras. 1-3, 35)

As part of the TUMRA agreement, Indigenous coastal native title applicants in Queensland who are included in the GBRMPA area must display a license on their boats, and must complete a form and submit it to GBRMPA each time they take a sea animal. This is part of the state's ongoing management of marine resources in the Great Barrier Reef and their strict control of its faunal environment.

I commented to the lawyers at North Queensland Land Council that at least in this case, native title applicants will henceforth be obliged to record each event of their traditional use of country and resources, which will undoubtedly prove to be an asset for the future protection of native title rights and interests. I will not dwell here on the way in which Indigenous use of country is regulated and policed by these mechanisms, because I think this distorts a moment of state self-constitution that is somewhat more subtle than that. Rather, I see this as a broader governmental policy that is non-partisan in nature and which can be summed up as the requirement to elicit Indigenous consent and ensure the continuing visibility of Aboriginal traditionality in certain kinds of initiatives having to do with resource use, land and environmental management. ${ }^{4}$ It is part of the way in which the $21^{\text {st }}$ century Australian polity is choosing to repatriate the Indigenous component of its national identity, and this moment of social and political consciousness goes far beyond native title in many important respects. What I am saying is that it is necessary for the consolidation of the Great Barrier Reef management vision for there to be visible Indigenous participation, of a traditional-looking nature.

As I said, a proviso in the agreement the Mamu signed with the GBRMPA stipulates that nothing in the agreement will be construed as having an effect on native title. In short, the rights offered to the Mamu and other coastal native title claim groups through their TUMRA are not native title rights, but nor do they undermine anything in the native title claim these groups have lodged.

\section{Statutory Inconsistency}

Native title groups all over the country are entering into such agreements in which they gain rights and authority over activities on their traditional land that they could 
never look forward to winning in a native title claim. In Victoria, for example, native title is a very recent formulation of Indigenous rights to country, and it has not displaced the older relations of regional Indigenous cultural heritage management that have existed under the aegis of the state government body known as Aboriginal Affairs Victoria. The map that shows the regional areas bears very little relationship to the cultural map of named groups engendered by the native title application process. In the Northern Territory, more than half of the land has been transferred to Aboriginal freehold title under the Aboriginal Land Rights Act (1976), which has resulted in many agreements between Aboriginal traditional owners and resource companies or national and state parks. The State of Queensland's Aboriginal Land Act (1983) has similarly granted rights in various state parks to Aboriginal traditional owners well before the Native Title Act (1993) was passed. ${ }^{5}$

From the point of view of social analysis, native title might well be a 'total social institution' as I have previously termed it. However, it has also proven to be far from the most empowering of the institutions of social inclusion that have allowed Indigenous people to have the semblance of a public presence in various land-based decision-making and stakeholder forums. Native title now plays its role as but one of the milestones along the pathway that Indigenous groups travel to achieve recognition in the broadest sense of the term. I do not see this as a specifically Australian issue either because almost exactly the same thing occurs in Papua New Guinea and elsewhere in other former settler states, like the US and Canada.

Indigenous traditional owners thus have different and inconsistent relations to their land depending on which law, statutory body or private concern they happen to be dealing with. The different relations are governed largely by what kind of tenure the government determined their traditional land happened to fall under in the postsovereignty period. ${ }^{6}$ In a non-native title agreement, Indigenous people are often offered rights that they never enjoyed before contact; in native title negotiations themselves, the most basic rights that they patently and demonstrably possessed before contact are commonly severely curtailed. What might Indigenous owners themselves be making of this inconsistency?

One of the problems that this might be creating is inconsistency in the way the law assesses the issue of continuity of traditional laws and customs that is required now in native title applications. If different private, government and statutory agencies are recognising Aboriginal identities and law and custom that are both contemporary and cannot be traced back to laws, customs or practices that existed at the time of sovereignty, they may be bequeathing difficulties to the next generation of native title holders. It seems that from an anthropological perspective, Indigenous communities are creating the conditions for internal inconsistencies that will have implications for the way their culture and legal rights are interpreted in the future. There are some political dimensions to these perceived effects of partiality on the articulation of Indigenous culture that we can then consider.

For is this not the dilemma that we all live under these days? If I were Papua New Guinean, for example, I might say that there are many 'roads' in life: the development 
road, the business road, the cultural heritage road, the road of kastom (i.e., traditional customary law) and the native title road, and that each one offers its own advantages and disadvantages (Filer 2006). However, none of them is the road, and none of them are to be spurned if there is a real advantage at the end of it. Whether all the roads add up to a single coherent set of pathways for any single Papua New Guinea village or villager is not the issue, because articulating a whole vision of society and its future is not necessarily one of the roads that you can get on there. In Papua New Guinea and in the parts of Aboriginal Australia I have worked in over the past twelve years, articulating the 'whole' was a very intermittent activity, hedged with restrictions and dangers, and only ultimately accessible by a select few with proven powers.

If I were an American of leftish-centrist persuasions, I might say that what the 1998 Wik amendments have done to native title, aided by over a decade since of harshly literalist and conservative judgements in the Federal and High Courts of Australia (with one or two exceptions), is to ensure that Indigenous traditional owners get more benefits outside of the determination 'road' than they do staying on that road. Native title, in 2011, does no more than buy Indigenous claimants a ticket to the bigger world of negotiation where we all live ( $c f$. Ritter 2009). After that, it is up to them to be as resolute, clever and effective as they can be to leverage what they can from the other stakeholders. If I were such an American, I might think this was not a bad thing, as it encouraged self-reliance and individual commitment and discouraged being dependent upon the capricious mercy of business, politicians, bureaucrats and the Australian voters.

\section{Conclusions: Inconsistency and Inter-Culturality}

I started out in this article lamenting the 'parsing' of Aboriginal society that our laws and vision of the social organism foist upon them. We can continue disparaging the naïve social science of judges and lawyers, we can continue defending the 'holistic' nature of Aboriginal society, and by that token, its insulation from all of the mechanisms of parsing that the modern world exerts on the rest of us. We can keep attributing radical alterity to Indigenous Australians knowing that such a categorisation precludes Australian society from any meaningful understanding of their culture, and social life. But the legal inconsistency I am talking about here, and its implications for the way cultural difference is articulated, is not synonymous with radical alterity. Its resolution, by the same token, has to by-pass the dead-end of such radical alterity.

We might be tempted, as I think some sub-Cape York Queensland NTRBs have been, unofficially or otherwise, to think that getting claimant groups ready to sign agreements is about the best success they can hope to achieve on behalf of their clients, and that struggling endlessly, and so far fruitlessly, for a consent determination is not going to materially add anything to the terms of these agreements - in fact, such struggles only threaten to imperil and curtail the rights and interests that they have garnered for themselves in many of those agreements. 
However, what I am really circling around is the difference between two kinds of recognition: the recognition of the traditionality of Indigenous Australians, and their status as traditional owners full stop, and the granting of substantive rights and property to them, rights and property they will henceforth be obliged to manage and protect. It is always a struggle to balance native title and Indigenous heritage with these two often competing and inconsistent goals. It is not clear to me after twelve years of writing, defending and refereeing anthropological reports associated with native title applications that many native title claim groups are altogether clear on how to manage both in relation to each other. However, recognising the partiality of our cultural portraits of traditionality is another way of recognising the engagement between such parts; and this is what I mean by the utter conventionality of inconsistency.

\section{Notes}

[1] http://www.nntt.gov.au/Applications-And-Determinations/Search-Applications (accessed 19 July 2011).

[2] Of course in regional systems, such as the one I have been working in recently in the Pilbara, a set of linked language groups have rights and responsibilities for segments of a single dreaming track relating to primary Creator Beings. Separately, their rights and responsibilities are partial in relationship to the whole, that is, the dreaming/creation story. Collectively, the regional system manages a far more 'complete' segment of that dreaming track. Local Aboriginal systems are therefore not, strictly-speaking, 'global' in every sense that Lévi-Strauss meant.

[3] Indigenous rights to 'sea country' were first recognised in the Croker Island native title application (Yarmirr $v$ Northern Territory [1998] FCA 1185) off the coast of the Northern Territory, which ultimately went to the High Court (Yarmirr v Northern Territory [2001] HCA 56). However, the extent of the sea boundary was much narrower than that encompassed by the Great Barrier Reef.

[4] This is an example of what Tim Rowse $(2002,179)$ calls 'organised instances of mobilisation' of Indigenous people.

[5] See Altman and Martin (2009) for other examples of benefits that Indigenous communities receive outside of native title, particularly in relation to resource agreements.

[6] Different tenure is largely related to the pattern of European settlement. Generally those areas settled first and more densely, such as in southeast Australia, were handed over to Europeans as freehold title, while in those areas settled later, particularly in northern Australia, the Europeans tended to secure a weaker form of title such as a pastoral lease.

\section{References}

Altman, J., and D. Martin. eds. 2009. Power, culture, economy: Indigenous Australians and mining. Centre for Aboriginal Economic Policy Research Monograph 30. Canberra: ANU E Press.

Filer, C. 2006. Custom, law and ideology in Papua New Guinea. The Asia Pacific Journal of Anthropology 7 (1): 65-84.

Glaskin, K. 2003. Native title and the 'Bundle of Rights' model: Implications for the recognition of Aboriginal relations to country. Anthropological Forum 13 (1): 67-88.

Levi-Strauss, C. 1969. The elementary structures of kinship. Boston: Beacon Press.

Lewis $v$ Wanganeen and Harradine [2005] SASC 36. 
Mabo v Queensland No 2. [1992] HCA 23.

Martin, D., and Mantziaris, C. 2000. Native title corporations: A legal and anthropological analysis. Sydney: The Federation Press.

Merlan, F. 1998. Caging the rainbow. Honolulu: University of Hawai'i Press.

Redfield, R. 1960. The little community. Chicago: University of Chicago Press.

Rigsby, B. 1998. A survey of property theory and tenure types. In Customary marine tenure in Australia. Oceania Monograph 48, edited by N. Peterson \& B. Rigsby, 22-46. Sydney: University of Sydney.

Ritter, D. 2009. The native title market. Nedlands: The University of Western Australia Press.

Rowse, T. 2002. Indigenous futures: Choice and development for Aboriginal and Islander Australia. Sydney: University of New South Wales Press.

Sutton, P. 2003. Native title in Australia: An ethnographic perspective. Cambridge: Cambridge University Press.

Strathern, M. 1999. Partial connections. Ann Arbor: University of Michigan Press.

Torres Strait Islanders $v$ State of Queensland No. 2 [2010] FCA 643.

Ward $v$ the State of Western Australia [2002] HCA 28.

Weiner, J. 2003. The law of the land. The Australian Journal of Anthropology 14 (1): 97-110.

Wik peoples $v$ the State of Queensland [1996] HCA 40.

Yanner v Eaton [1999] HCA 53.

Yarmirr v Northern Territory [1998] FCA 1185.

Yarmirr v Northern Territory [2001] HCA 56.

Yorta Yorta $v$ the State of Victoria [2002] HCA 58. 